\title{
Obesity and Environmental Pollutants
}

\author{
Açelya GÜL, Binnur Okan Bakir ${ }^{1^{*}}$
}

${ }^{1}$ Department of Nutrition and Dietetic, Yeditepe University

*Corresponding author: Binnur OKAN BAKIR, 1Department of Nutrition and Dietetic, Yeditepe University, Tel: +90 021657800-1657; E-mail: binnur.bakir@yeditepe.edu.tr

\begin{abstract}
:
Obesity is a global health problem in recent years. Adipose tissue was known as a storage tissue increasing with rise of the body mass index the indicator of obesity. The endocrine functions of adipose tissue might contribute to obesity, diabetes mellitus, cancer and infertility. Many environmental chemicals affect actions of hormones so these chemicals have been defined as endocrine-disrupting chemicals(EDCs) or endocrine disruptors. With the increase in production of EDCs in the world parallels the global obesity prevalence increases. The reported rise in obesity of children under 2 years of age is also suggestive of alterations during development. In early life EDCs exposure can influence epigenetic programming of obesity. These pollutants can pass from mother to fetus via placenta and breast feeding. Some obesogens are found in nature such as phytoestrogens and the others are mostly synthetic chemicals. These chemicals commonly found in pesticides /herbicides, industrial and household products, plastics detergents and personal care products. These substances are defined persistant organic pollutant (POPs) and they accumulate in adipose tissue. Common EDSs are Tributyltin (TBT), 4-Nonylphenol used in industry, persistent organochlorines (POPs) used in agriculture industry, diethylstilboestrol (DES) as a pharmaceutical, bisphenol A (BPA) and phthalates used in plastics, parabens as preservatives, phytoestrogens in edible plants, polybrominated diphenylethers (PBDEs) as flame retardants. We searched current literature with the key words: obesogens, POPs, endocrine disruptors in pubmed and filtered the results with articles in recent 5 years. This mini reviewprovides current experience about association between obesity and endocrine disrupting chemicals.
\end{abstract}

Keywords: Obesity; Endocrin disrupting chemicals; Environmental pollutants

\section{Introduction}

Obesity is a global health problem in recent years ${ }^{[1,2]}$. Adipose tissue was known as a fat storage tissue increasing with the rise of the body mass index the indicator of obesity. Recently it is well known that adipose tissue is not only a storage tissue but also has endocrine and metabolic functions ${ }^{[3]}$. The major body weight regulators and inflammatory agents such as leptin, peroxisome proliferator-activated receptors (PPARs) is controlled by adiposetissue. These regulators stimulate food intake, metabolic efficiency, and energy storage ${ }^{[4,5]}$. The endocrine functions of adipose tissue might contribute to obesity, diabetes mellitus, cancer and infertility ${ }^{[6]}$.

Many environmental chemicals affect actions of hormones so these chemicals have been defined as endocrine-disrupting chemicals(EDCs) or endocrine disruptors ${ }^{[1,7]}$. With the increase in production of EDCs in the world parallels the global obesity prevalence increases ${ }^{[8,9]}$. Obesogens as xenobiotic chemicals which bring about decreasing detoxification mechanism of body can alter the normal progress of adipogenesis or energy balance $e^{[3,8,10,11]}$. Some obesogens are found in nature such as phytoestrogens and the others are mostly synthetic chemicals. These chemicals commonly found in pesticides /herbicides, industrial and household products, plastics detergents and personal care products $^{[1,7]}$. These synthetic chemicals are enduring so they do not degrate in the nature. For this reason these substances are defined persistant organic pollutant (POPs) and they accumulate in adipose tissue ${ }^{[12-14]}$. They are lipophilic and bioaccumulate in the food chain and human body. As they are lipophilic they accumalte in fat tissue. More obese the individual is more chemicals are accumulated and more accumulated chemicals induces more fat deposit as they are endocrine disruptors and damages the endocrine control of body weight ${ }^{[1]}$. Common EDSs are Tributyltin (TBT), 4-Nonylphenol used in industry, persistent organochlorines (POPs) used in agriculture industry, diethylstilboestrol (DES) as a pharmaceutical, bisphenol A (BPA) and phthalates

\section{Received Date: September 21, 2017 \\ Accepted Date: May 21, 2018 \\ Published Date: May 24, 2018}

Citation: Okan Bakir, B., et al. Obesity and Environmental Pollutants. (2018) J diab Obes 5(1): 18- 21.

Copyright: (C) 2018 Okan Bakir, B. This is an Open access article distributed under the terms of Creative Commons Attribution 4.0 International License. 
used in plastics, parabens as preservatives, phytoestrogens in edible plants, polybrominated diphenylethers (PBDEs) as flame retardants $^{[1]}$. Tributyltin (TBT) used as a biocide in antifouling paints applied to the hulls of ships and cause imposex in molluscs and to masculines female fish ${ }^{[1,15]}$. TBT may inhibit aromatase which is responsible for the conversion of testosteron into estrogens ${ }^{[1,16,17]}$. 4-Nonylphenol is has eustrogenic effets and used as asurfactan in industry and domestic applicarion ${ }^{[1,18,19]}$. POPs are used mostly as insecticides (DDT, DDE), Diethylstilbestrol (DES) is a non steroidal estrogen.The DES toxicity includes its interference with reproductive system and association with female reproductive tract cancers ${ }^{[1,20]}$. Bisphenol A a componenet of polycarbonat plastics and resins. It is ubiquitous in food and beverage containers, baby bottles,toys, dental sealants.Foods and beverage can be contaminated by BPA as a result of heating or acidic/basic condition during storage ${ }^{[1,8]}$. Phythalates are diester of phthalic acid. They are used in commonly plastic scuh as polyvinyl chloride and some products such as food and beverage packaging, soaps, shampoos,cosmetics and hair sprays ${ }^{[8]}$. Parabens are mostly found in personal care products, foods, pharmaceutical products and paper products ${ }^{[1,21]}$. Phytoestrogens are found naturally in plant such as soy and soy products. They are defined dietary estrogens. Increased consumption of soy products and soy supplements cause exposure to phytoestrogens.Genstein which is predominant isoflavon in soybean is responsible of changes in the metabolic and adipogenic regulators such as PPAR gama ${ }^{[8,21,23]}$. Recent experimental data supported that genistein dysregulates the body composition, in a dose-dependent and gender-specific manner, disrupting and reprogramming the signals dictating adipose tissue expansion, likely throughout the early-life epigenetic regulation of Wnt10b, a further key adipogenic gene in adipose tissue ${ }^{[8,24]}$. Polychlorinated Bisphenols are organic chemicals and found in electricam equipment.Some PBCs are identified as EDCs because of their estrogenic and antiandrogenic effects ${ }^{[8,25]}$. Although PCBs were banned at the end of the 1970s in many countries because of environmental toxicity, these compounds still remain present in the environment due to their high stability and represent one of the key constituents of POPs all over the world ${ }^{[8,26]}$. Perfluoroalkyl substances are non organochlorine POPs used in industrial applications.PFASs are detectable in human blood ${ }^{[8]}$.

Pesticides consumption is the most important source of EDCs exposure ${ }^{[1,27]}$. Two main types of pesticided are organochlorine and organophosphate pesticides. Although Organochlorine pesticides was banned, they are still detected in tap water. Organophosphate pesticides have replaced organochlorine ${ }^{[1,27]}$. These pesticides enter into food chain and tends to persist environment and accumulate human body ${ }^{[8,28]}$. Human body might exposure to these chemicals with oral intake by contaminated water and food consumption, respiration, or dermal absorption ${ }^{[1,7]}$. EDCs related obesitymay involve in several mechanisms. EDCs distrupt lipid and glucose metabolism(endocrine regulated metabolic process) and also neuroendocrine control of appetite and satiety ${ }^{[1,9,16,29,30]}$. MoreoverEDCs affect pro inflammatory mechanisms by activating oxidative stress- sensitive transcription factors such as nuclear factor kappa B (NFKB) stimulating cytokines, chemokines and adhesion molecules in the vascular endothelium. Along the pro-inflamatory mechanisms, EDCs are associated with an increased risk of non communicable or chronic diseases such as cardivascular diseases or diabetes and insulin resistance ${ }^{[1,16,31,32]}$. As EDCs are accumulated in fat tissue several studies shown an increasing in blood POPs following fat loss when obese individuals lose weight with diet or bariatric surgery, with approximately $30 \mathrm{~kg}$ decrease in fat mass ${ }^{[3,33,34]}$.

Gender, dose, life stage and duration of EDCs exposure is important $t^{[1]}$. In obesogen hypothesis, EDCs effect obesity related epigenetic variations and microbiata profile. EDCs stimulate expression of noncoding RNAs, changes in chromatin structure and DNA and histone methylation. Low levels of DNA methylation can produce active adipogenic genes so adipocyte number increases.Increasing active adipogenic genes may change metabolic set point ${ }^{[8,35]}$. According to set point theory, body weight sustains stable from internal regulatory mechanisms that are genetically determined ${ }^{[36]}$. Change in metabolic set point causes weight regain after weight $\operatorname{loss}^{[8,35]}$.

In 14 th week of gestation, adipogenesis begins ${ }^{[8,37]}$ and goes on during postnatal period ${ }^{[6,38]}$. The reported rise in obesity of children under 2 years of age is also suggestive of alterations during development ${ }^{[1,39,40]}$. Studies shown that babies born to mother who smoked tobacco during pregnancy have been found to have a low birth weight but later this babies are at increased risk of obesity ${ }^{[1,41]}$. Other study of children in the Faroe Island shown that prenatal exposure to polychlorinated bisphenols and dikloro difenil dikloroetilencontained in seafood is related with increased body weight ${ }^{[1,42]}$. In early life EDCs exposure can influence epigenetic programming of obesity ${ }^{[1]}$. These pollutants can pass from mother to fetus via placenta and breast feeding ${ }^{[43,44]}$.

In a cohort conducted in 189 adult obese individuals aimed evaluation of POPs level in visceral and subcutaneous adipose tissue has found that both were affected with POPs but visceral adipose tissue was more sensitive to accumulation. Additionally they found a relationship between increased POPs accumulation and increased metabolic risk as dysglycemia and high blood pressure had positive relationhip with elevated POPs level ${ }^{[44]}$.

A rodent model experiment female mice were fed with high fat and high sucrose diet with or without pollutants. The pollutants were prepared as a mixture of low doses. It contained 'Tolerable Daily Intake (TDI)' doses of tetrachlorodibenzo-p-dioxin, PCB, bisphenol A and phthalate. Each pollutant was used at a dose grossly corresponding to the TDI reference dose. They found that mice fed with pollutants even at TDI doses had increased body weight, plasma fasting glycose and plasma insulin levels. Additionally found out that metabolic aoutcomes were sex and age depended that female were more sensitive to exposure in diffrerent stages of life $\operatorname{span}^{[42]}$.

One of the main issues of the world is obesity which is related to genetic and environmental factors. Although obesity is related with excessive food consumption or lack of exercise with the increasing industrialization it is also associated with strongly environmental factors such as synthetic chemicals and pollutants. These substances accumulate adipose tissue and mimic endocrine hormones. The early exposure to EDCs in prenatal and postnatal period which is especially before 2 years of life increases risk for adulthood obesity. When considering the relationship between obesity and EDCs, production of EDCs must be controlled by policies and exposure to these substances especialy early life stages should be reduced. 
Abbreviatıons: PPARS: Peroxisome Proliferator Activated Receptors; EDCs: Endocrine Disrupting Chemicals; POPs: Persistant Organic Pollutant; TBT:Tributytin; DES: Diethylstilbestrol; BPA: Bisphenol A; PBDEs: Polybrominated Diphenylethers; DDT: Dikloro Difenil Trikloroethan; DDE: Dikloro Difenil Dikloroetilen

\section{References}

1. Darbre, P.D. Endocrine and Disruptors and Obesity. (2017) Curr Obes Rep 6(1): 18-27.

PubMed |CrossRef $\mid$ Others

2. OECD. Obesity update. June 2014. Accessed 8 Feb 2017. Statistics showing the rise in obesity.

PubMed $\mid$ CrossRef $\mid$ Others

3. Merril, M.L., Emond, C., Kim, M.J., et al. Toxicological Function of Adipose Tissue:Focus on Persistent Organic Pollutatnts. (2013) Environ Health Perspect 121(2): 162-169.

PubMed | CrossRef | Others

4. Grün, F., Blumberg, B. Environmental Obesogens: Organotins and Endocrine Disrupion via Nuclear Receptor Signaling. (2006) Endocrinology 147(6 Suppl): S50-S55.

PubMed | CrossRef | Others

5. Auwerx, J. PPAR gama, the Ultimate Thrifty Gene. (1999) Diabetologia 42(9): 1033-1049.

PubMed | CrossRef | Others

6. Janesick, A.S., Blumberg, B. Obesogens: an Emerging Threat to Public Health. (2016) Am J Obstet Gynecol 214(5): 559-565.

PubMed | CrossRef | Others

7. Darbre, P.D. Endocrine disruption and human health. New York: Academic; Overview of EDCs and human health which sets the bigger picture (2015).

PubMed $\mid$ CrossRef $\mid$ Others

8. Nappi, F., Barrea, L., Somma, C.D., et. al. Endocrine Aspects of Environmental “Obesogens” Pollutants. (2016) Int J Environ Res Public Health 13(8):765.

PubMed | CrossRef | Others

9. Gore, A.C., Chappell, V.A., Fenton, S.E., et al. EDC-2: The Endocrine Society's second scientific statement on endocrine-disrupting chemicals. (2015) Endocr Rev 36(6): E1-E150.

PubMed | CrossRef | Others

10. Barouki, R. Linking long-term toxicity of xeno-chemicals with short-term biological adaptation. (2010) Biochimie 92(9): 12221226.

PubMed | CrossRef | Others

11. Grün, F., Blumberg, B. Environmental obesogens: Organotins and endocrine disruption via nuclear receptor signaling. (2006) Endocrinology 147(6 Suppl): S50-S55.

PubMed | CrossRef | Others

12. Ozonoff, D., Aschengrau, A., Coogan, P. Cancer in the vicinity of a department of defense superfund site in Massachusetts. (1994) Toxicol Ind Health 10(3): 119-141.

PubMed | CrossRef | Others
13. Li, Q.Q., Loganath, A., Chong, Y.S., et al. Persistent organic pollutants and adverse health effects in humans. (2006) J Toxicol Environ Health A 69(21): 1987- 2005.

PubMed | CrossRef $\mid$ Others

14. Pestana, D., Faria, G., Sa, C., et. al. Persistent Organic Pollutant Levels in Human Visceral and Subcutaneous Adipose tissue in Obese Individuals- Depot Differences and Dysmetabolism implications. (2014) Environ Res 133: 170-177.

PubMed | CrossRef $\mid$ Others

15. Horiguchi, T. Masculinization of female gastropod mollusks induced by organotin compounds, focusing on mechanism of actions of tributyltin and triphenyltin for development of imposex. (2006) Environ Sci 13(2): 77-87.

PubMed | CrossRef $\mid$ Others

16. Saitoh, M., Yanase, T., Morinaga, H., et al. Tributyltin or triphenyltin inhibits aromatase activity in the human granulosa-like tumor cell line KGN. (2001) Biochem Biophys Res Commun 289(1): 198-204.

PubMed | CrossRef $\mid$ Others

17. Cooke, G.M. Effect of organotins on human aromatase activity in vitro. (2002) Toxicol Lett 126(2): 121-130.

PubMed | CrossRef $\mid$ Others

18. OECD (Organisation for Economic Cooperation and Development). The 2004 OECD list of high production volume chemicals. (2004) Environment Directorate, Paris.

PubMed | CrossRef $\mid$ Others

19. White, R., Jobling, S., Hoare, S.A., et al. Environmentally persistent alkylphenolic compounds are estrogenic. (1994) Endocrinology 135(1): 175-182.

PubMed | CrossRef $\mid$ Others

20. Koebnick, C., Smith, N., Coleman, K.J., et al. Prevalence of extreme obesity in a multiethnic cohort of children and adolescents. (2010) J Pediatr 157(1): 26-31.

PubMed |CrossRef $\mid$ Others

21. Darbre, P.D., Harvey, P.W. Parabens can enable hallmarks and characteristics of cancer in human breast epithelial cells: a review of the literature with reference to new exposure data and regulatory status. (2014) J Appl Toxicol 34(9): 925-938.

PubMed |CrossRef $\mid$ Others

22. Patisaul, H.B., Jefferson, W. The pros and cons of phytoestrogens. (2010) Front Neuroendocrinol 31(4): 400-419.

PubMed $\mid$ CrossRef $\mid$ Others

23. Penza, M., Montani, C., Romani, A., et al. Genistein affects adipose tissue deposition in a dose-dependent and gender-specific manner. (2006) Endocrinology 147(12): 5740-5751.

PubMed | CrossRef | Others

24. Strakovsky, R.S., Lezmi, S., Flaws, J.A., et al. Genistein exposure during the early postnatal period favors the development of obesity in female, but not male rats. (2014) Toxicol Sci 138(1): 161-174. PubMed | CrossRef $\mid$ Others

25. Portigal, C.L., Cowell, S.P., Fedoruk, M.N., et al. Polychlorinated biphenyls interfere with androgen-induced transcriptional activation and hormone binding. (2002) Toxicol Appl Pharmacol 179(3): 
$185-194$

PubMed $\mid$ CrossRef $\mid$ Others

26. Ghosh, S., Murinova, L., Trnovec, T., et al. Biomarkers linking PCB exposure and obesity. (2014) Curr Pharm Biotechnol 15(11): $1058-1068$.

PubMed | CrossRef | Others

27. Slotkin, T.A. Does early-life exposure to organophosphate insecticides lead to prediabetes and obesity? (2011) Reprod Toxicol 31(3): 297-301. PubMed | CrossRef | Others

28. Mostafalou, S. Persistent organic pollutants and concern over the link with insulin resistance related metabolic diseases. (2016) Rev Environ Contam Toxicol 238: 69-89.

PubMed | CrossRef | Others

29. Rubin, B.S. Bisphenol A: an endocrine disruptor with widespread exposure and multiple effects. (2011) J Steroid Biochem Mol Biol 127(1-2): 27-34.

PubMed | CrossRef | Others

30. Report of the Proceedings of the European workshop on the impact of endocrine disrupters on human health and wildlife. Weybridge, UK. Report EUR17549 of the Environment and Climate Change Research Programme of DGXII of the European Commission. 1996.

PubMed | CrossRef $\mid$ Others

31. Kamrin, M.A. Phthalate risks, phthalate regulation and public health: a review. (2009) J Toxicol Environ Health Part B Crit Rev 12(2): 157-174.

PubMed | CrossRef | Others

32. Bramwell, L., Glinianaia, S.V., Rankin, J., et al. Associations between human exposure to polybrominated diphenyl ether flame retardants via diet and indoor dust, and internal dose: a systematic review. (2016) Environ Int 92-93: 680-694.

PubMed | CrossRef | Others

33. Hue, O., Marcotte, J., Berrigan, F., et al. Increased plasma levels of toxic pollutants accompanying weight loss induced by hypocaloric diet or by bariatric surgery. (2006) Obes Surg 16(9): 1145-1154.

PubMed | CrossRef $\mid$ Others

34. Kim, M.J., Marchand, P., Henegar, C., et al. Fate and complex pathogenic effects of dioxins and polychlorinated biphenyls in obese subjects before and after drastic weight loss. (2011) Environ Health Perspect 119(3): 377-383.

PubMed | CrossRef | Others

35. Cheikh Rouhou, M., Karelis, A.D., St-Pierre, D.H., et al. Adverse effects of weight loss: Are persistent organic pollutants a potential culprit? (2016) Diabetes Metab 42(4): 215-23.

PubMed | CrossRef | Others

36. Mahan, L.K., Escott-Stump, S., Krause, M.V. Krause's food \& nutrition therapy. (2017) Elsevier Saunders 385.

PubMed $\mid$ CrossRef $\mid$ Others

37. Poissonnet, C.M., Burdi, A.R., Garn, S.M. The chronology of adipose tissue appearance and distribution in the human fetus. (1984) Early Hum Dev 10(1-2): 1-11.

PubMed | CrossRef | Others
38. Spalding, K.L., Arner, E., Westermark, P.O., et al. Dynamics of fat cell turnover in humans. (2008) Nature 453(7196): 783-787.

PubMed | CrossRef $\mid$ Others

39. Kim, J., Peterson, K.E., Scanlon, K.S., et al. Trends in overweight from 1980 through 2001 among preschool-aged children enrolled in a health maintenance organization. (2006) Obesity14(7): 11071112 .

PubMed | CrossRef $\mid$ Others

40. Koebnick, C., Smith, N., Coleman, K.J., et al. Prevalence of extreme obesity in a multiethnic cohort of children and adolescents. (2010) J Pediatr 157(1): 26-31.

PubMed |CrossRef | Others

41. Power, C., Jefferis, B.J. Fetal environment and subsequent obesity: a study of maternal smoking. (2002) Int J Epidemiol 31(2): 413-419.

PubMed | CrossRef | Others

42. Tang-Péronard, J.L., Heitmann, B.L., Andersen, H.R., et al. Association between prenatal polychlorinated biphenyl exposure and obesity development at ages 5 and $7 \mathrm{y}$ : a prospective cohort study of 656 children from the Faroe Islands. (2014) Am J Clin Nutr 99(1): 5-13.

PubMed |CrossRef $\mid$ Others

43. Naville, D., Labaronne, E., Vega, N., et al. Metabolic Outcome of Female Mice Exposed to a Mixture of Low-Dose Pollutants in a Diet Induced Obesity Model. (2015) PloS one 10(4): e0124015. PubMed | CrossRef | Others

44. Heindel, J.J., vom Saal, F.S. Role of nutrition and environmental endocrine disrupting chemicals during the perinatal period on the aetiology of obesity. (2009) Mol Cell Endocrinol 304(1-2): 90-96. PubMed | CrossRef | Others

Submit your manuscript to Ommega Publishers and we will help you at every step:

- We accept pre-submission inquiries

- Our selector tool helps you to find the most relevant journal

- We provide round the clock customer support

- Convenient online submission

- Thorough peer review

- Inclusion in all major indexing services

- Maximum visibility for your research

Submit your manuscript at

OMMEgA Publishers

https://www.ommegaonline.org/submit-manuscript 